\title{
CAMA
}

Centre for Applied Macroeconomic Analysis

\section{Impacts of a Capacity Advantaged Bidder in Sequential Common Value Auctions: Evidence from the Laboratory}

\section{CAMA Working Paper 17/2014 February 2014}

Kalyn T. Coatney

Mississippi State University

Dale J. Menkhaus

University of Wyoming

\section{Sherrill Shaffer}

University of Wyoming and

Centre for Applied Macroeconomic Analysis

\section{Abstract}

As bidders reach capacity throughout a sequential common value auction, theory predicts they will account for the option value of purchasing later units against fewer rivals. Mergers, joint purchasing arrangements, or a common bidding agent may result in a capacity advantaged bidder. Using laboratory experiments, we find that bidders account for the option value of winning later units when capacity constraints are significantly binding. Similar to the predictions of value advantaged bidder theory, the capacity advantaged bidder bids more aggressively, purchasing more units at lower prices than disadvantaged rivals. However, the creation of a capacity advantaged bidder transfers surplus to all bidders primarily due to the reduction in the number of bidders. 


\section{Keywords}

\section{JEL Classification}

\section{Address for correspondence:}

(E) cama.admin@anu.edu.au

The Centre for Applied Macroeconomic Analysis in the Crawford School of Public Policy has been established to build strong links between professional macroeconomists. It provides a forum for quality macroeconomic research and discussion of policy issues between academia, government and the private sector.

The Crawford School of Public Policy is the Australian National University's public policy school, serving and influencing Australia, Asia and the Pacific through advanced policy research, graduate and executive education, and policy impact. 
Impacts of a Capacity Advantaged Bidder in Sequential Common Value Auctions:

\title{
Evidence from the Laboratory
}

\author{
Kalyn T. Coatney \\ Dept. of Agricultural Economics \\ Mississippi State University \\ P.O. Box 5187, 365 Lloyd-Ricks-Watson Bldg. \\ Mississippi State, MS 39762 \\ 662-325-7983 \\ coatney@agecon.msstate.edu
}

\author{
Dale J. Menkhaus \\ Dept. of Agricultural \& Applied Economics \\ University of Wyoming Dept. 3354 \\ 1000 E. University Ave. \\ Laramie, WY 82071 \\ 307-766-5128 \\ menkhaus@uwyo.edu
}

\author{
Sherrill Shaffer \\ Dept. of Economics \& Finance \\ University of Wyoming Dept. 3985 \\ 1000 E. University Ave. \\ Laramie, WY 82071 \\ and Centre for Applied Macroeconomic Analysis (CAMA) \\ The Australian National University \\ 307-766-2173 \\ shaffer@uwyo.edu
}




\title{
Impacts of a Capacity Advantaged Bidder in Sequential Common Value Auctions:
}

\author{
Evidence from the Laboratory
}

\begin{abstract}
As bidders reach capacity throughout a sequential common value auction, theory predicts they will account for the option value of purchasing later units against fewer rivals. Mergers, joint purchasing arrangements, or a common bidding agent may result in a capacity advantaged bidder. Using laboratory experiments, we find that bidders account for the option value of winning later units when capacity constraints are significantly binding. Similar to the predictions of value advantaged bidder theory, the capacity advantaged bidder bids more aggressively, purchasing more units at lower prices than disadvantaged rivals. However, the creation of a capacity advantaged bidder transfers surplus to all bidders primarily due to the reduction in the number of bidders.
\end{abstract}

\section{Introduction}

Advantaged bidder theory predicts that a value advantaged bidder in common value auctions strategically bids more aggressively resulting in higher bids than would otherwise be expected when common values are the same for all bidders (Bikhchandani 1988; Klemperer 1998; Rose and Kagel 2008). The aggressive bidding reduces competition by enhancing the winner's curse of a disadvantaged rival. In a sequential multi-unit auction, the value advantaged bidder would be expected to purchase most, if not all, units at prices below those of a disadvantaged rival resulting in asymmetric prices and quantities between these two bidder types. Therefore, a disadvantaged bidder earns less surplus than the advantaged bidder and less surplus than when common values are the same for all bidders.

Laboratory research has not supported the value advantaged bidder theory (Levin and Kagel 2005; Rose and Levin 2008). Recent empirical research of prices in English auctions for cattle, however, has observed such asymmetries between an allegedly cost (value) advantaged bidder (a common agent representing a collaboration of beef processors) and independent bidders (Coatney, Shaffer and Menkhaus 2012). Prices also were significantly less than regional 
averages indicating a reduction in competition (Coatney, Shaffer and Menkhaus 2012; Coatney and Tack 2011). While the degree of cost advantage held by the common bidding agent could not be explicitly identified, holding multiple purchase orders from some of the largest firms likely resulted in a capacity advantage for the agent. There is both theoretical and empirical evidence of reduced competition in English auctions resulting from a value advantaged bidder. Could there also be a capacity advantage that contributes to reduced competition?

Our research contributes to the literature by exploring the potential for a capacity advantage based explanation of reduced competition and asymmetric prices and quantities between advantaged and disadvantaged bidders in an English auction setting. Generally speaking, when at least some bidders are expected to reach capacity before the end of an auction, bidders are expected to shade their bids in accordance with the option value of winning later units against fewer rivals (Weber 1983; Bernhardt and Scoones 1994; Fatima, Wooldridge and Jennings 2005). A capacity advantage can arise when a subset of capacity constrained firms either merge, purchase units at an auction through a joint purchasing arrangement, or form a buyer collaboration by hiring a common bidding agent. Mergers are common place across all industries and joint purchasing arrangements and common bidding agents are prevalent in the crude oil, health care and livestock industries (Hendricks and Porter 1992; FTC/DOJ 1996; USDA, GIPSA 2008).

Because asymmetries in capacity can occur after a subset of similarly sized firms combine their purchases, we must also simultaneously address the competitive impacts resulting from the creation of a capacity advantaged bidder. In doing so, we design two treatments to be tested in the laboratory - symmetric and asymmetric capacity constraints. Bidding agents have identical purchase or capacity requirements in the symmetric case. In the latter treatment, an 
advantaged bidder is created by a hypothetical joint purchasing venture. The asymmetric treatment increases the likelihood that all but the advantaged bidder reaches capacity before the end of the auction period. Therefore, as a robustness check, we allow for a fairly restrictive auctioneer/seller reservation price in the laboratory experiment to combat the potential for single bidder competition toward the end of the auction.

Results from sequential common value English auction laboratory experiments indicate that the capacity advantaged buyer bids more aggressively than disadvantaged bidders, and the advantaged bidder is able to purchase more units at prices below those purchased by the disadvantaged bidders. These results are consistent with current value advantage theory. There also is evidence of option value bidding as bidders shade their bids for early units, especially in the presence of a capacity advantaged bidder. Furthermore, the creation of the advantaged bidder transfers a significant amount of surplus to both advantaged and disadvantaged competitors. These results are robust in the presence of restrictive seller reservation prices.

\section{Bidding in Common Value English Auctions}

We present the theory that provides the basis for comparison in our estimated bidding equations presented later. Under the following bidding strategy it is assumed that either capacity constraints do not impact bidding decisions or bidders simply fail to recognize the possibility of reduced competition for later units.

We begin by assuming that $i=1, \ldots, n$ symmetric firms (bidders) compete for multiple units offered during the auction period, $q=1, \ldots, Q$. Because bidders ignore or fail to recognize future reductions in competition, we can ignore the unit's subscript. Following Levin, Kagel and Richard (1996), the true common value, $x_{0}$, for each unit is independently and identically drawn 
from a uniform distribution with supports $(\bar{x}-\underline{x})$. Each bidder's private signal $P S_{i}$ for each unit is then independently and identically drawn from the uniform distribution with supports $\left[\max \left(\underline{x}, x_{0}-\varepsilon\right), \min \left(\bar{x}, x_{0}+\varepsilon\right)\right] \cdot{ }^{1}$ The $\varepsilon$, which is common knowledge, can be thought of as bidder expertise in evaluating the true common value.

As the bidding ascends in a common value English auction, the one-shot risk-neutral Nash equilibrium (RNNE) bidding strategy when capacity constraints are non-binding for the $i=3 \leq n$ bidders is for the lowest private value signal holder to drop out of the bidding when their signal is reached (Milgrom and Weber 1982; Levin, Kagel and Richard 1996). ${ }^{2}$ All dropout bids are perfectly observable and are common knowledge to all market participants. From the information conveyed by the first drop-out bid, the $n-1$ bidders still in the bidding optimally drop out in accordance with their updated unbiased estimate of the true common value (reservation bid). This strategy protects bidders against adverse selection, thus mitigating the effects of "winners curse". The ordered vector of RNNE drop-out bids is

$\mathbf{d}_{i, j}^{*}=\left[\begin{array}{llll}P S_{i, 1} & \frac{\left(P S_{-i, 2}+d_{i, 1}\right)}{2} & \ldots & \frac{\left(P S_{-i, h}+d_{i, 1}\right)}{2}\end{array}\right]$.

${ }^{1}$ The authors refer to the area of the joint unconditional distribution of private signals and common values when $\max \left(\underline{x}, x_{0}-\varepsilon\right)=\underline{x}$ as region $1,\left[\left(x_{0}-\varepsilon\right),\left(x_{0}+\varepsilon\right)\right]$ as region 2 and $\min \left(\bar{x}, x_{0}+\varepsilon\right)=\bar{x}$ as region 3. Interestingly, in region 1, if $x_{0}=\underline{x}$ then all private signals drawn are greater than the true common value.

${ }^{2}$ This presumes that the auctioneers initial asking bid is below the lowest private signal held by the bidders. 
Bidders are observed to drop out of the bidding in order of their ranked private signals $S_{i, j}$, where $j=1$ is the lowest up to $j=h$, the highest private signal. The $d_{i, 1}^{*}=P S_{i, 1}$ is the first bidder observed to drop out of the bidding and the $d_{-i, 1<j<h}^{*}=\frac{\left(P S_{-i, 1<j<h}+d_{i, 1}\right)}{2}$ are the subsequent observed drop-out bids. The winner holding the highest private signal $\left(s_{-i, h}\right)$ wins the bid and pays the second highest drop-out bid, $d_{-i, h-1}^{*}=\frac{\left(P S_{-i, h-1}+d_{i, 1}\right)}{2}$.

Because $n \geq 3$ may not be guaranteed before the end of the auction period as capacity constraints bind, we further consider the cases if $n$ reaches two or one. If $n=2$ are remaining for the $q \leq Q$ units, again $x_{0}$ is independently and identically drawn for each unit from a uniform distribution with supports $(\bar{x}, \underline{x})$. For simplicity we assume private signals are independently and identically drawn from the uniform distribution with supports $\left[x_{0}-\varepsilon, x_{0}+\varepsilon\right] .^{3}$ Letting $\underline{\chi}=x_{0}-\varepsilon, \bar{\chi}=x_{0}+\varepsilon$, the $k^{\text {th }}$ highest private signal order statistic is $E_{P S(k)}=\underline{\chi}+\left(\frac{n+1-k}{n+1}\right)(\bar{\chi}-\underline{\chi})$. Even with only two bidders, the dominant strategy in an English auction is for the lowest private signal holder to drop out of the bidding first (Milgrom and Weber 1982). If the low private signal bidder were to continue bidding and win, the expected price paid is greater than the true common value, an irrational decision. The highest signal holder's best response is to wait for the lowest signal bidder to drop out. In the eventuality there is ever an uncontested bidder, $n=1$, we assume the auctioneer establishes a reservation price

\footnotetext{
${ }^{3}$ These are region 2 of the joint unconditional distribution of private signals and common values.
} 
equal to lowest expected private signal $r=E_{P S(k=n)}=\underline{\chi}+\frac{1}{(n+1)}(\bar{\chi}-\underline{\chi}) \forall q\left(\mathrm{n}^{\text {th }}\right.$ highest order statistic) rather than letting an item go for bid of zero.

\section{Capacity Constraint Considerations}

Because firms that compete for common value objects such as crude oil and cattle for processing typically maintain excess capacity (USDA, GIPSA 2007; Corts 2008), we are specifically concerned about the impact of what we will define later as a partially binding capacity constraint. Previous option value bidding research by Fatima, Wooldridge and Jennings 2005 assumes bidders hold unit or symmetric capacity. Therefore, the number of bidders is necessarily reduced by one as the auction period progresses. However, in a more realistic multi-unit demand (capacity) setting, predicting the level of competition for later units is not as straightforward as reducing the bidders by one across each unit offered for sale. To predict which unit each of $n$ bidders expect to reach capacity, $C_{i}$, we utilize the negative binomial distribution. ${ }^{4}$ The negative binomial distribution predicts the $q^{\text {th }}$ unit each bidder unilaterally expects to reach capacity at $\bar{q}_{i}=\frac{C_{i}-1}{p}+1$, where the probability of winning any given unit is $p_{i}=\frac{1}{n}$ when bidders have the same common values and follow symmetric bidding strategies in that no one bidder bids more

\footnotetext{
${ }^{4}$ The negative binomial distribution is mathematically represented as $P(Q=q \mid s, p)=\left(\begin{array}{c}q-1 \\ r-1\end{array}\right) p^{s}(1-p)^{(q-s)} \quad q=s, s+1, \ldots$, with mean $\frac{s}{p}$ and variance $\frac{s(1-p)}{p^{2}}$, where $p=1 / n$ is the probability $n$ symmetric bidders win any given unit, $s=C_{i}$ and $Q$ is auction supply.
} 
aggressively/passively than their rival(s). ${ }^{5}$ When an industry holds excess capacity, $\sum_{i=1}^{n} C_{i}>Q$, this implies each bidder's capacity is greater than the expected number of units they will purchase $C_{i}>E\left[q_{i}\right]$, where $E\left[q_{i}\right]=\frac{Q}{n}$. For capacities to be non-binding, in the sense that every bidder expects to compete for every unit, industry excess capacity is such that $\bar{q}_{i} \geq Q{ }^{6}$ For capacities to be partially binding, bidders expect one less competitor at unit $\bar{q}+1$ but do not expect to win any unit uncontested such that $\bar{q}_{i}+1 \leq Q<\sum_{i=1}^{n} C_{i} \cdot{ }^{7}$ For capacities to be fully binding, all bidders expect to face no competition for at least the last unit sold, therefore, $\sum_{i=1}^{n} C_{i} \leq Q \cdot{ }^{8}$ A common simplifying assumption is that bidders replace their expectations of the path of competition throughout the auction session with their certainty equivalents (Wilson 1979). Unlike the unit-demand (capacity) theory of Fatima, Wooldridge and Jennings (2005), the number of bidders is expected to remain constant from units $q=1 \rightarrow \bar{q}_{i}$ and then steadily

\footnotetext{
${ }^{5}$ Under asymmetric bidding strategies, $p_{i}$ would be endogenously determined.

${ }^{6}$ For example, let $n=5, Q=10$ and $C_{i}=3$. Total industry capacity is $15>Q$. Therefore, $\bar{q}=11>Q$.

${ }^{7}$ For example, let $n=5, Q=12$ and $C_{i}=3$. Total industry capacity is $15>Q$. Therefore, $\bar{q}=11<Q$ and $\sum_{i=1}^{n} C_{i}=15>Q$.

${ }^{8}$ For example, let $n=5, Q=15$ and $C_{i}=3$. Total industry capacity is $15=Q$. Therefore, $\bar{q}=11<Q$ and $\sum_{i=1}^{n} C_{i}=15=Q$.
} 
decline. We will demonstrate, however, that the creation of a capacity advantaged bidder under partially binding capacity constraints could result in the capacity advantaged bidder facing no competition for later units in the auction period.

\section{Experiment Treatments and Hypotheses}

We design two treatments to test the impacts of creating a capacity advantaged bidder on competition in a laboratory English auction setting. The two treatments are designated as (1) symmetric capacity (SC) and (2) asymmetric capacity (AC) created by a joint purchasing venture of a subset of symmetric capacity firms. In designing the treatments, we select parameters that result in partially binding capacity constraints in the SC treatment and become more binding in the AC treatment.

\subsection{Symmetric Capacity Treatment}

In the SC treatment, there are $n=5$ equally capacity constrained buyers (firms). Each bidder's potential purchases per auction period is $C_{i}=3$ units resulting in an industry capacity of

$\sum_{i=1}^{n} C_{i}=15$ units. The quantity offered for sale per auction period is restricted to $Q=12$, resulting in a 20 percent over capacity. These parameters meet the partially binding capacity constraint in that each of the five bidders has an equal chance of reaching capacity by unit 11 , and no bidder expects to purchase any unit uncontested. Each bidder can expect to purchase between 2 and 3 units per auction period. Because bidders expect one less competitor for the last unit, there is an incentive for bidders to shade their bids throughout the auction period. 


\subsection{Asymmetric Capacity Treatment}

In the $\mathrm{AC}$ treatment, we form a joint purchasing venture among three out of the five firms. This results in three remaining bidders competing in the auction - one capacity advantaged bidder (AB) and two capacity disadvantaged bidders (DB).

The AB's capacity is nine units, commanding a dominant position in total capacity. Assuming symmetric bidding strategies, each of the two DBs and the $\mathrm{AB}$ expect to purchase three and six units, respectively. Because the negative binominal distribution does not guarantee clearly defined expected competition break points in all circumstances, the final determination of the expected number of bidders across the full auction period is provided in Appendix A. Given symmetric bidding strategies, the DBs are expected to begin reaching capacity by unit 7 and all will reach capacity by unit 9 . The $A B$ is expected to win 50 percent of all units available during the auction period, the last three uncontested. Hence, the creation of the joint purchasing venture results in a capacity advantage, enhancing the likelihood the $A B$ will win more units at lower prices than the DBs. Furthermore, because all DB are expected to reach capacity before the end of the auction period, the potential for bid shading and the resulting buyer revenue is enhanced.

\subsection{Hypotheses}

The following are the null hypotheses we empirically test in the laboratory for each treatment. Competition from disadvantaged bidders may be reduced due to their submission of lower bids (Bikhchandani 1988; Klemperer 1998; Rose and Kagel 2008).

$\mathrm{H}_{0} 1$ (Asymmetric Prices and Quantities): Without asymmetric capacities, asymmetric prices and quantities between bidders cannot persist. 
Some bidders are expected to reach capacity before the end of the auction by design and to a greater extent in the AC treatment, given the predictions of Weber (1983) Bernhardt and Scoones (1994) and Fatima, Wooldridge and Jennings (2005).

$\mathrm{H}_{0} 2$ (Option Value Bidding): Both the first and subsequent bidders to drop out do not shade their bids in either treatment below the RNNE bidding strategy.

Overall competition may be reduced due to the reduction in the number of bidders and lower submitted bids by disadvantaged bidders, given the predictions of Bikhchandani (1988), Klemperer (1998) Rose and Kagel (2008).

$\mathrm{H}_{0} 3$ (Surplus Transference): The joint purchasing venture does not transfer surplus from sellers to buyers.

\section{Experimental Design}

We conduct a series of three sessions for each of the two treatments. Each session consists of six separate auction periods. Within each auction period, there are 12 individually auctioned units via the irrevocable exit ascending "clock" method where the auctioneer's starting price is less than the lowest private signal for the unit and increases incrementally until the second to last bidder exits (Levin, Kagel and Richard 1996). In total, 216 units were auctioned for each treatment.

Randomly drawn common values and private signals per bidder identification and unit auctioned remain the same across each of the six experimental sessions to control for bidding and anomalies across treatments that may arise simply due to each bidder's randomly drawn private signal. Special consideration was given regarding a perceived value advantage in the AC treatment when forming the joint purchasing venture. Because the randomly drawn private signal means within the experimental session were the highest for bidders one and two, we chose 
bidder three to purchase on behalf of these two bidders in order to mitigate the potential influence of a real value advantage. ${ }^{9}$

Subjects were recruited from graduate students in economics and finance, as well as from upper-division mathematics courses. Instructions were read by the experimenter, questions addressed, and a post-instruction quiz was given to insure that each subject understood the instructions. The essential features of a common value English auction were incorporated into the laboratory auction to test the above hypotheses. Subjects were provided information of i) the number of bidders, ii) the number of auction periods, iii) the number units offered for sale per auction period, iv) each bidder's capacity constraint, v) subject identification by bidder type (DB or $\mathrm{AB}$ ), vi) the number of firms comprising the joint purchasing venture, vii) the payoff functions of all bidders, and viii) the seller's reservation price is equal to some expected lowest private signal.

Practice rounds were conducted to familiarize subjects with the procedures of the auction and data entry into an electronic buyer's card (Excel spreadsheet). To begin the auction, asking bids were projected on a screen in the front of the room. Unknown to the subjects, the algorithm for auctioneer's asking bid (ASB) for the $q^{\text {th }}$ unit sold was $A S B_{q}=\min \left(s_{1, q}-2, r_{q}\right)$, where $s_{1, q}$ is the lowest ranked private signal actually drawn for the $q^{\text {th }}$ unit sold and $r_{q}$ is the seller's reservation price. The seller's reservation price equaled the lowest expected private signal calculated from the distribution of private signals for each unit sold. Each ASB was well below expected levels of bid shading. Subjects were given a bidding paddle embossed with a number

\footnotetext{
${ }^{9}$ Mean (standard deviation) private value draws across the six auction periods were 59.81 (20.75), 58.42 (20.80), 56.94 (20.68) for bidders 1 through 3, respectively, and 55.45 (20.57), and 54.10 (20.79) for bidders 4 and 5, respectively.
} 
to identify the bidder, dropping their paddle to indicate exit from bidding. Subjects were able to see who was bidding, closely monitored by the experimenter, and not allowed to communicate by talking or using gestures.

Finally, though negative aggregate surpluses are not expected given the reservation bid training, subjects started with small unknown symmetric equal endowments. Aside from a $\$ 5.00$ show-up fee, the endowment was set large enough to mitigate potential bankruptcies and kept unknown to avoid overly aggressive bidding due to limited liability (Hansen and Lott, 1991; Loureiro, Umberger and Hine 2003).

\subsection{Mitigating Subject Learning of the Winner's Curse}

Experience matters, especially in the brutal environment of common value auctions (Garvin and Kagle 1994; Levin, Kagel and Richard 1996; Kagel and Richard 2001; Casari, Ham and Kagel 2007). Our subject pool had no prior experience in common value auctions. To enhance their attention to the issues of capacity constraints, we informed our novice bidders about the winner's curse and demonstrated how to avoid it by forming a reservation bid from the bid of the first bidder to drop out of the bidding. ${ }^{10}$ At no time were the subjects informed that the reservation bid was an equilibrium bidding strategy of any kind. Each bidder recorded the first drop-out bid in electronic bidding sheets. Remaining active bidders were provided an updated reservation bid in accordance with equation (1).

\subsection{Backward Induction and Subgame Perfection Ability}

\footnotetext{
${ }^{10}$ Because of the importance of the winner's curse, employers spend considerable time and resources training new buyers before 'turning them loose'.
} 
We attempt to control for each subject's ability to choose subgame perfect bidding strategies. Understanding the option value of winning later units requires the agent to backward induct a fairly complex auction game. Experimental subjects routinely struggle with the cognitive requirements, the expense of backward induction, as well as issues of trust and other human behavior (McKelvey and Palfrey 1992; Fey, McKelvey and Palfrey 1996; Johnson et. al. 2002; Binmore et. al. 2002; Palacios-Huerta and Volij 2009; Levitt, List and Sadoff 2011).

Prior to conducting the auction experiment, subjects were given a one-shot simultaneous choice four stage increasing pie centipede game (figure 1). Subjects were the "You" player and were matched against the experimenter "Me". Subject ability to evaluate credible threats/promises they face in real world, "Me" further stated "If you are willing to wait, I will split the $\$ 4.00$ of my budget that I have to play with you. What will you do?” To avoid potential contamination of the subsequent auction experiment by endowments and relationship between the experimenter and subjects, experiment participants were not informed of the experimenter's choice or of their payoffs until completion of the session.

\subsection{Risk Aversion}

We also attempt to control for each subject's risk aversion. Prior to conducting the auction experiment, a risk aversion test following Holt and Laury (2002) (table 1) was administered. Although the dominant bidding strategy in common value English auctions does not rely on risk aversion, if bidders are risk averse, they would likely bid lower than predicted by risk neutrality (Levin, Kagel and Richards 1996; Kagel 1995). The more important consideration in our experimental setting is that bidders may partially focus on the risk of not fulfilling their capacity or expected number of purchases. This may be especially true for the capacity advantaged bidder 
who is less likely to reach capacity. As a result, risk averse bidders may bid more aggressively (Buccola 1982; Ashenfelter 1989; McAfee and Vincent 1993).

\section{Empirical Estimation and Results}

We begin by describing general outcomes from the two treatments. The remainder of this section is comprised of the empirical tests of the null hypotheses stated above.

\subsection{General Description of Data and Results}

The relevant data from the experiment sessions include bidder characteristics derived from the pre-tests, drop-out bids, bidder identification, wins per bidder, surpluses, and earnings per unit. The data revealed that 56 percent of the actual winners matched the predicted winner in the SC treatment and 74 percent for the AC treatment. Hence, efficiency was improved by the creation of a capacity advantaged bidder.

A summary of the risk aversion pre-test is provided in table 1 . In general, most (2/3) subjects did not switch from the less risky lottery option (A) to the riskier lottery option (B) until after paired lottery choice 5, the risk neutral switching point. Some in fact did not switch to the more risky option until lottery 9, indicating extreme risk aversion. From the centipede game, roughly 71 percent of the subjects correctly chose the subgame perfect equilibrium strategy of "take" in the first round suggesting the majority of the study participants exhibited the ability to backward induct and evaluate threats/promises that are not credible.

In the SC treatment, the bidding data consisted of 221 of 216 possible first drop-out bids and 495 of 648 subsequent possible drop-out bids because of drop-out ties and bidders reaching capacity. In the AC treatment, the bidding data consisted of 166 of 162 possible first drop-out bids and 102 of 126 subsequent possible drop-out bids because of drop-out ties, bidders reaching 
capacity, and the $\mathrm{AB}$ regularly winning the last three units uncontested (figure 2). Consistent with the negative binomial predictions, unit 9 is the average point in the auction where the $A B$ faced the last DB.

Other aspects of the bidding data include instances when the seller's reservation price was binding upon the sale price. In the SC and AC treatments, the seller's reservation price was binding for two and 49 percent of the purchases, respectively. If the buyer refused to accept the seller's reservation price the unit was not sold (no-sale). There were six observed no-sales in the $\mathrm{AC}$ treatment recorded, three by $\mathrm{DBs}$ and three by the $\mathrm{AB}$ and none in the $\mathrm{SC}$ treatment. In these instances, the winner's updated reservation bid was less than the seller's reservation price.

\subsection{Asymmetric Prices and Quantities Hypothesis}

We now test whether asymmetric capacities result in asymmetric prices and quantities between the $\mathrm{AB}$ and DBs. We estimate the following winning bid (price dependent) empirical model separately for each treatment by Ordinary Least Squares. Using only the data of the highest (denoted $1 \leq j \leq h$ ) bidder to drop out of the bidding, the estimated price (winning bid) equation for each treatment and simulation is

$$
P_{h q}=\beta_{0}+\beta_{1} C V_{q}+\beta_{2} A B_{h i q}+\sum_{r=3}^{4} \beta_{r} S_{h d q}+\varepsilon_{h l q}
$$

where: $P_{h q} \equiv$ price paid for the $q^{\text {th }}$ unit auctioned, $1 \leq q \leq Q ; \beta_{0} \equiv$ intercept; $C V_{q} \equiv$ true common value for the $q^{\text {th }}$ unit; $A B_{\text {hiq }} \equiv \mathrm{AB}$ dummy variable in the symmetric treatment where $i=1$ if one of the potential joint venture firms were to win the $q^{\text {th }}$ unit auctioned and 0 otherwise, alternatively, the $\mathrm{AB}$ dummy variable in the asymmetric treatment where $i=1$ if the $\mathrm{AB}$ wins the $q^{\text {th }}$ unit auctioned and 0 otherwise; $S_{h 2 q}$ and $S_{h 3 q} \equiv$ auction session dummy variables, where $d=1$ 
w.r.t. auction sessions 2 or 3 and 0 otherwise; and $\varepsilon_{l q}=\rho \varepsilon_{l(q-1)}+v_{l q}$, where $l$ indicates the respective auction session (1, 2 or 3$)$ cross-section.

The true common value is included as a proxy for the changing average private signals/reservation bids per unit. According to general theory we expect $\beta_{1}>0$. For comparison purposes, the SC treatment results for $\beta_{2}$ (test for asymmetric prices) control for a potential joint venture among bidders 1, 2 and 3 . In the $\mathrm{AC}$ treatment, bidder 3 is the $\mathrm{AB}$ representing the joint venture. Bidders designated as 4 and 5 remain the same in both treatments.

The auction session variables are included to capture any unique group dynamics. For instance, a group may generally be more risk averse, or perform poorly at solving for subgame perfection. Also, subjects in the experiment were recruited from a pool of students who may have prior relationships, or develop unobservable synergies during the experiment, the type and extent to which are unknown. As such, the sign of the coefficient on each auction session is unknown.

The data are arranged in a time series fashion across auction sessions, auction periods and units auctioned within period. The data include all units purchased less the six no-sales in the AC treatment. Auction session represents the cross-section within the time series of observables. The change in subjects across each auction session may cause some disruption to the time series components of the model. Auction period is not a cross section as the series contains the same set of subjects. Therefore, to test for serial correlation, we follow a procedure suggested in Greene (2003, 317-318). The aggregate model including all auction sessions is first estimated. Corresponding rho's are then estimated for each cross-section. A Durbin-Watson test statistic is calculated based on the average estimated rho per cross-section. If serial correlation is determined to be a problem, the data are transformed by the Yule-Walker procedure. 


\subsubsection{Results}

Results of the estimated treatment equations (2) are provided in table 2. Based on $\mathrm{R}^{2}$, both models fit the data quite well. Not surprisingly, the underlying true common value in both treatments provides the greatest contribution to the dependent variable, winning bid. Prices paid across auction sessions were significantly different from one another, hence indicating some unobservable synergies existed within groups of bidders.

In the SC treatment, there were no statistical differences in prices paid between the hypothetical joint purchasing venture and the two latter disadvantaged bidders. Hence, no apparent value advantages were perceived among the potential joint purchasing venture members. However, in the $\mathrm{AC}$ treatment the $\mathrm{AB}$ paid significantly lower prices on average than the DBs, regularly purchasing the last three units uncontested (figure 2), and purchased roughly 50 percent of the total units available as predicted (table 3 ). Therefore, we reject the null, $H_{0} 1$, and conclude that with asymmetric capacities, asymmetric prices and quantities between the $A B$ and DBs persist.

\subsection{Option Value Bidding Hypothesis}

We now test whether bidders shade their bids indicative of option value bidding in each treatment. The estimated bidding models are estimated separately in two stages. Following the RNNE bidding equation (1), the first stage is the bidding function of the first bidder to drop out. The second stage bidding function consists of all those bidders remaining in the bidding, excluding the winner.

Using only the data of the first bidder (or bidders in case of a tie) observed to drop out, (denoted $j=1$ ), the first bidding model is 
$D_{1 q}=\lambda_{0}+\lambda_{1} P S_{1 q}+\lambda_{2} A B_{1 i q}+\sum_{r=3}^{5} \lambda_{r} \operatorname{Risk}_{1 s q}+\lambda_{6} \operatorname{SubPerf}_{1 z q}+\sum_{r=7}^{8} \lambda_{r} S_{1 d q}+\varepsilon_{1 l q}$

where: $D_{1 q} \equiv$ the observed first drop-out bid for the $q^{\text {th }}$ unit sold; $\lambda_{0} \equiv$ the intercept; $P S_{1 q} \equiv$ the private signal held by the first bidder to drop-out of the bidding for the $q^{\text {th }}$ unit sold and is equal to the risk neutral Nash equilibrium (RNNE) bidding strategy denoted in equation (1); $A B_{1 i q} \equiv$ same definition as equation (2), but only applies to the AC treatment; Risk $k_{1 s q} \equiv$ three dummy variables where $s=1$ at the subject's switching point from the safer to riskier option is at the paired lottery 6,7 or 8 and $9^{11}$, and 0 otherwise, where the base comparison is a switching point of paired lottery 5 (risk neutral) and higher values increasing in risk aversion; SubPerf $f_{1 z q} \equiv$ dummy variable where $z=1$ if the subject incorrectly answered the subgame perfect pre-test (ability to backward induct) and 0 otherwise; $S_{1 d q}$ and $\varepsilon_{11 q}$ are the same definitions as in equation (2).

Using the data of all subsequent bidders observed to drop out and not win the unit, (denoted $1<j<h$ ), the second bidding model is

$$
\begin{aligned}
D_{(1<j<h) q} & =\gamma_{0}+\gamma_{1} R B_{(1<j<h) q}+\gamma_{2} A B_{(1<j<h) i q}+\sum_{r=3}^{5} \gamma_{r} \operatorname{Risk}_{(1<j<h) s q}+\gamma_{6} \operatorname{SubPerf}_{(1<j<h) z q} \\
& +\sum_{r=7}^{8} \gamma_{r} S_{(1<j<h) d q}+\varepsilon_{(1<j<h) l q}
\end{aligned}
$$

where: $D_{(1<j<h) q} \equiv$ any $j^{\text {th }}$ observed ordered drop-out bid from $1<j<h$ for the $q^{\text {th }}$ unit sold, $\lambda_{0} \equiv$ intercept; $R B_{(1<j<h) q}=\frac{P S_{(1<j<h) q}+D_{1 q}}{2} \equiv$ updated reservation bid which is equal to the risk neutral Nash equilibrium (RNNE) bidding strategy denoted in equation (1); $A B_{i q} \equiv$ same definition as

\footnotetext{
${ }^{11}$ Switching points 8 and 9 are combined due to collinearity problems found during estimation.
} 
equations (2) and (3), but only applies to the AC treatment to test for possible asymmetric bidding; Risk $k_{(1<j<h) s q}$ and SubPerf $f_{(1<j<h) z q} \equiv$ same definitions as in equation (3); and $S_{(1<j<h) d q}$ and $\varepsilon_{1<j<h, l q} \equiv$ same definitions as equations (2) and (3).

We estimate both reduced and full models for each treatment to check the robustness of bid shading indicative of option value bidding. The reduced models are absent controls for bidder characteristics and group dynamics and thus are identified by the RNNE bidding model. The RNNE bidding model imposes the restrictions that the intercept coefficients $\lambda_{0}$ and $\gamma_{0}=0$ and $\lambda_{1}$ and $\gamma_{1}=1$. Though losing the full structural identification, we choose to regress the observed data's updated reservation bid, $R B_{(1<j<h) q}$, on drop-out bids because i) subjects were specifically educated on the value of reservation bidding via sufficient statistics to mitigate the winner's curse and ii) $R B_{(1<j=h) q}$ was provided in subjects electronic cards.

By controlling for the $\mathrm{AB}$ in the $\mathrm{AC}$ treatment, we are able to test whether bidder knowledge of asymmetric capacity constraints is manifested in asymmetric bidding. Given the earlier symmetric price results, we do not control for a potential joint purchasing venture in the SC treatment. In both treatments we expect higher risk aversion to result in higher drop-out bids. Bidders who understand backward induction and subgame perfection are expected to shade their drop-out bids, more so in the AC treatment. No expectations can be derived for the impacts of auction session.

Data are maintained in the same cross-section time-series fashion as in the price estimation of equation (2), as well as in order of drop outs for each unit sold, and serial correlation is tested and addressed in the same manner. Again, each auction session of the 
treatments represents the cross-sections of the data. F-tests are conducted to test the intercept restrictions for evidence of bid shading.

\subsubsection{Bidding Function Results}

The Ordinary Least Squares results of the first and subsequent drop-out bidding functions are provided in table 4 . Based on $\mathrm{R}^{2}$, all reduced and full models fit the data quite well. With the exception of the SC's full model for the first drop-out bid, the intercept is not significantly less than zero. This suggests bidders in the SC treatment did not significantly shade their bids, thus indicating that bidders did not weigh the option value of winning the last of twelve units with one less bidder. However, all AC model intercepts were significantly less than zero. Therefore, bidders significantly shaded their bids indicating that the three bidders accounted for the option value of winning later units. Given these results, we fail to reject the option value bidding null, $H_{0}$ 2, across drop-out bids for the symmetric capacity treatment. However, we reject the option value bidding null, $H_{0}$ 2, for the asymmetric capacity treatment and conclude that with asymmetric capacities both first and subsequent bidders shade their bids below a RNNE bidding strategy without partially binding capacity constraints.

In all the reduced and full models, the strongest explanatory variables were private signals for the first to drop out and the updated reservation bid for subsequent drop-out bids. From the full model estimations, more risk averse bidders tended to submit higher bids in the SC treatment only. Those who performed well at the subgame perfection test (centipede game) generally shaded their bids more those who did not, but particularly in the AC treatment. With the exception of the first bidders to drop out in the SC treatment, auction session did not appear to impact the results. Finally, the capacity advantaged bidder's drop-out bids were significantly higher than the disadvantaged bidders indicating a more aggressive bidding strategy. 


\subsection{Surplus Transference Hypothesis}

The observed (OBS) and simulated RNNE average prices, average per unit surpluses per treatment are provided in table 5. No subject experienced bankruptcy. Though not statistically different, subjects paid on average slightly more than expected under RNNE in the SC treatment and earned less surplus per unit than if they had engaged in a RNNE strategy. Also not statistically different in the AC treatment, prices were slightly less, and per unit surpluses slightly higher, than those expected when bidders follow a RNNE strategy. Average per unit prices were not statistically different in the AC treatment, but were roughly one token less or $10 \%$ of the possible private signal range. However, the average per unit surpluses was significantly higher in the AC treatment. Therefore, we reject the null, $\mathrm{H}_{0} 3$, and conclude that the joint venture transfers surplus from sellers to buyers.

\section{Conclusions}

Capacity constraints can significantly impact the bidding behavior and outcomes, especially in the case of a capacity advantaged bidder. We extend unit-demand sequential common value English auction literature by incorporating realistic multi-unit demand and a limited degree of excess industry capacity. The impacts of capacity constraints and the creation of a capacity advantaged bidder on competition in a laboratory auction are observed. The creation of asymmetric capacities, potentially by a joint venture, merger or common bidding agent, can significantly alter the strategic interactions among the remaining bidders resulting in reduced competition and asymmetric outcomes of price and quantity between a capacity advantaged and disadvantaged bidders. 
Our results indicate that the asymmetric outcomes of price and quantity are largely driven by the capacity advantage. The advantaged bidder in our study is able to win later units uncontested after smaller disadvantaged bidders meet their capacities. The advantaged bidder, facing less competition than the disadvantaged bidders, is observed to pay lower prices on average than disadvantaged bidders. Average per unit price, though not statistically smaller, was found to be economically depressed by roughly 10 percent after the formation of the joint purchasing venture. Taken together, the predicted and observed market outcomes associated with a capacity advantaged bidder are similar to those predicted by value advantaged bidder theory and observed empirically (Bikhchandani 1988; Klemperer 1998; Rose and Kagel, 2008; Coatney, Shaffer and Menkhaus 2012).

Contrary to value advantaged bidder theory, we find a positive externality from the presence of a capacity advantaged bidder. The surpluses of the disadvantaged bidder are significantly enhanced, rather than reduced, primarily because there are fewer competing bidders. Our empirical evidence also suggests that the reduction in competition is potentially greater when a bidder is both value and capacity advantaged. For instance, the merger or joint venture may simultaneously reduce transactions costs conferring both a capacity and value advantage.

Though we also find that the capacity advantaged bidder bids more aggressively than disadvantaged bidders, our results are not directly comparable with value advantaged bidder theory. Value advantaged bidder theories do not account for i) the source, potentially from an ex ante strategic choice, ii) the sustainability of the advantage, nor iii) the potential for changes in industry structure resulting from such an advantage. Therefore, our results suggest that further 
theoretical and empirical investigations of various forms and combinations of capacity and value advantages are warranted.

We find that bidder characteristics are important considerations, especially when there are many bidders. Not surprisingly, bidders who perform poorly at backward induction may not have considered the reduction in competition for latter units and were thus unable to take full advantage of option value bidding. Risk averse bidders in the more competitive atmosphere of the no-collaboration treatment appear to have traded off per unit surpluses with the desire to purchase more units.

Finally, we observe an unexpected finding. A statistically significant transfer of surplus from seller to buyer does not require a statistically significant decrease in average prices. The impacts of strategic choices seem to be masked by the noise of random valuations and bids across multiple units. This pattern suggests that empirical analyses of anticompetitive behavior in real world sequential common-value auctions that do not find a statistical difference in prices cannot conclude that competition was not significantly reduced (Porter 2005). 
Table 1: Holt and Laury Risk Aversion Pre-test and Results

\begin{tabular}{|c|c|c|c|c|c|}
\hline \multicolumn{6}{|c|}{$\begin{array}{c}\text { Ten Paired Lottery-Choice } \\
\text { Decisions }\end{array}$} \\
\hline Lottery & Option A & Option B & $\begin{array}{l}\text { Expected Payoff } \\
\text { Difference by } \\
\text { Choosing } \\
\text { Option A over B }\end{array}$ & $\begin{array}{l}\text { Choose } \\
\text { Option B }\end{array}$ & $\begin{array}{c}\text { Percent of } \\
\text { Subject Pool } \\
\text { Switching from } \\
\text { Option A to B }\end{array}$ \\
\hline 1 & $\begin{array}{l}1 / 10 \text { of } \$ 5.00 \\
9 / 10 \text { of } \$ 4.00\end{array}$ & $\begin{array}{c}1 / 10 \text { of } \$ 10.00 \\
9 / 10 \text { of } \$ 0.25\end{array}$ & 2.875 & insane & 1 \\
\hline 2 & $\begin{array}{l}2 / 10 \text { of } \$ 5.00 \\
8 / 10 \text { of } \$ 4.00\end{array}$ & $\begin{array}{c}2 / 10 \text { of } \$ 10.00 \\
8 / 10 \text { of } \$ 0.25\end{array}$ & 2.000 & $\begin{array}{l}\text { highly risk } \\
\text { loving }\end{array}$ & 0 \\
\hline 3 & $\begin{array}{l}3 / 10 \text { of } \$ 5.00 \\
7 / 10 \text { of } \$ 4.00\end{array}$ & $\begin{array}{c}3 / 10 \text { of } \$ 10.00 \\
7 / 10 \text { of } \$ 0.25\end{array}$ & 1.125 & $\begin{array}{l}\text { very risk } \\
\text { loving }\end{array}$ & 0 \\
\hline 4 & $\begin{array}{l}4 / 10 \text { of } \$ 5.00 \\
6 / 10 \text { of } \$ 4.00 \\
\end{array}$ & $\begin{array}{c}4 / 10 \text { of } \$ 10.00 \\
6 / 10 \text { of } \$ 0.25\end{array}$ & 0.025 & $\begin{array}{l}\text { slightly risk } \\
\text { loving }\end{array}$ & 0 \\
\hline 5 & $\begin{array}{l}5 / 10 \text { of } \$ 5.00 \\
5 / 10 \text { of } \$ 4.00\end{array}$ & $\begin{array}{c}5 / 10 \text { of } \$ 10.00 \\
5 / 10 \text { of } \$ 0.25\end{array}$ & -0.625 & risk neutral & 29.17 \\
\hline 6 & $\begin{array}{l}6 / 10 \text { of } \$ 5.00 \\
4 / 10 \text { of } \$ 4.00\end{array}$ & $\begin{array}{c}6 / 10 \text { of } \$ 10.00 \\
4 / 10 \text { of } \$ 0.25\end{array}$ & -1.500 & $\begin{array}{l}\text { slightly risk } \\
\text { averse }\end{array}$ & 29.17 \\
\hline 7 & $\begin{array}{l}7 / 10 \text { of } \$ 5.00 \\
3 / 10 \text { of } \$ 4.00\end{array}$ & $\begin{array}{c}7 / 10 \text { of } \$ 10.00 \\
3 / 10 \text { of } \$ 0.25\end{array}$ & -2.375 & $\begin{array}{l}\text { very risk } \\
\text { averse }\end{array}$ & 25.00 \\
\hline 8 & $\begin{array}{l}8 / 10 \text { of } \$ 5.00 \\
2 / 10 \text { of } \$ 4.00\end{array}$ & $\begin{array}{l}8 / 10 \text { of } \$ 10.00 \\
2 / 10 \text { of } \$ 0.25\end{array}$ & -3.250 & $\begin{array}{l}\text { highly risk } \\
\text { averse }\end{array}$ & 8.33 \\
\hline 9 & $\begin{array}{l}9 / 10 \text { of } \$ 5.00 \\
1 / 10 \text { of } \$ 4.00\end{array}$ & $\begin{array}{c}9 / 10 \text { of } \$ 10.00 \\
1 / 10 \text { of } \$ 0.25\end{array}$ & -4.125 & $\begin{array}{l}\text { extremely risk } \\
\text { averse }\end{array}$ & 8.33 \\
\hline 10 & $\begin{array}{c}10 / 10 \text { of } \$ 5.00 \\
0 / 10 \text { of } \$ 4.00\end{array}$ & $\begin{array}{c}10 / 10 \text { of } \$ 10.00 \\
0 / 10 \text { of } \$ 0.25\end{array}$ & -5.000 & comatose & 0 \\
\hline
\end{tabular}


Table 2: Results of Testing Null Hypotheses 1 (Asymmetric Prices)

\begin{tabular}{lc|c}
\hline \hline & $\begin{array}{c}\text { Symmetric } \\
\text { Capacity } \\
\text { (5 Bidders) }\end{array}$ & $\begin{array}{c}\text { Joint Venture and } \\
\text { Asymmetric Capacity } \\
\text { (3 Bidders) }\end{array}$ \\
\hline Winning Bid & $\begin{array}{c}\text { Coefficient } \\
\text { (Std. Error) }\end{array}$ & $\begin{array}{c}\text { Coefficient } \\
\text { (Std. Error) }\end{array}$ \\
\hline Intercept & -0.72 & $-0.79^{* *}$ \\
& $(0.43)$ & $(0.37)$ \\
$\mathrm{CV}^{1}$ & $0.996^{*}$ & $0.987^{*}$ \\
$\mathrm{AB}^{2}$ & $(0.006)$ & $(0.005)$ \\
& 0.07 & $-0.50^{* *}$ \\
$\mathrm{~S}_{2}$ & $(0.25)$ & $(0.21)$ \\
& $0.816^{*}$ & $0.655^{*}$ \\
$\mathrm{~S}_{3}$ & $(0.295)$ & $(0.260)$ \\
\hline $\mathrm{R}^{2}$ & $0.671^{* *}$ & $0.587^{*}$ \\
$\mathrm{D}-\mathrm{W}$ & $(0.295)$ & $(0.262)$ \\
\hline $\mathrm{Si}^{*}$ & 0.993 & 0.995 \\
& 2.00 & 2.08 \\
\hline
\end{tabular}

*Significantly different from 0 at $\alpha=.01$.

** Significantly different from 0 at $\alpha=.05$.

${ }^{1}$ OLS estimates are reported as the null of no serial correlation cannot be rejected. The estimated rho's for the symmetric treatment model across auction sessions are $.09,-0.02$ and -0.07 . The estimated rho's for the asymmetric treatment model across auction sessions are $0.05,0.06$ and -0.13 . The Durbin-Watson $(\mathrm{D}-\mathrm{W})$ is approximated by $2\left(1-\mu_{\rho}\right)$.

${ }^{2}$ The advantaged bidder $(\mathrm{AB})$ in the symmetric treatment compares the price differential between the potential joint venture firms to firms excluded from the joint venture. 
Table 3: Results of Testing Null Hypotheses 1 (Asymmetric Quantities): Average Percent Purchases by Treatment and Bidder Type - Observed and Predicted

\begin{tabular}{|c|c|c|c|c|}
\hline \multirow{3}{*}{ Strategy } & \multicolumn{2}{|c|}{$\begin{array}{l}\text { Symmetric Capacity } \\
\text { (5 Bidders) }\end{array}$} & \multicolumn{2}{|c|}{$\begin{array}{l}\text { Joint Venture and Asymmetric Capacity } \\
\qquad \text { (3 Bidders) }\end{array}$} \\
\hline & \multicolumn{2}{|c|}{$\begin{array}{c}\text { Average Total Purchases per } \\
\text { Auction Period }\end{array}$} & \multicolumn{2}{|c|}{$\begin{array}{c}\text { Average Total Purchases per Auction } \\
\text { Period }\end{array}$} \\
\hline & $\begin{array}{c}\text { Bidders } \\
1 \text { to } 3 \\
\text { (obs=648) }\end{array}$ & $\begin{array}{l}\text { Bidders } \\
4 \text { and } 5 \\
\text { (obs=432) }\end{array}$ & $\begin{array}{l}\text { Advantaged } \\
\text { Bidder } 3 \\
(\text { obs }=648)\end{array}$ & $\begin{array}{l}\text { Disadvantaged } \\
\text { Bidders } 4 \text { and } 5 \\
\quad(\text { obs }=432)\end{array}$ \\
\hline Observed & $\begin{array}{r}0.20 \\
(0.40)\end{array}$ & $\begin{array}{c}0.21 \\
(0.40)\end{array}$ & $\begin{array}{l}0.50^{\mathrm{a}} \\
(0.50)\end{array}$ & $\begin{array}{l}0.24^{\mathrm{a}} \\
(0.43)\end{array}$ \\
\hline Predicted & $\begin{array}{l}0.19 \\
(0.39)\end{array}$ & $\begin{array}{c}0.22 \\
(0.41)\end{array}$ & $\begin{array}{l}0.50^{\mathrm{a}} \\
(0.50)\end{array}$ & $\begin{array}{l}0.25^{\mathrm{a}} \\
(0.43)\end{array}$ \\
\hline
\end{tabular}

\footnotetext{
${ }^{a}$ Shaprio-Wilk test rejects the null of normality for symmetric capacity and asymmetric capacity at the $\alpha=0.01$. The one tailed Wilcoxon Two-Sample Test rejects the null that purchases by the capacity advantaged bidder are not greater than the disadvantage bidder at the $\alpha=0.01$.
} 
Table 4: Capacity Treatment Results Testing Null Hypotheses 2 (Option Value Bidding) and Hypotheses 3 (Aggressive Bidding)

\begin{tabular}{|c|c|c|c|c|c|c|c|c|}
\hline & \multicolumn{4}{|c|}{$\begin{array}{l}\text { Symmetric Capacity } \\
\text { (5 Bidders) }\end{array}$} & \multicolumn{4}{|c|}{$\begin{array}{l}\text { Joint Venture and Asymmetric Capacity } \\
\text { (3 Bidders) }\end{array}$} \\
\hline & \multicolumn{2}{|c|}{$\begin{array}{c}\text { First } \\
\text { Drop-Out Bids }\end{array}$} & \multicolumn{2}{|c|}{$\begin{array}{c}\text { Subsequent } \\
\text { Drop-Out Bids }\end{array}$} & \multicolumn{2}{|c|}{$\begin{array}{c}\text { First } \\
\text { Drop-Out Bids }\end{array}$} & \multicolumn{2}{|c|}{$\begin{array}{c}\text { Subsequent } \\
\text { Drop-Out Bids }\end{array}$} \\
\hline & $\begin{array}{l}\text { Reduced } \\
\text { Model }^{1}\end{array}$ & $\begin{array}{c}\text { Full } \\
\text { Model }^{2}\end{array}$ & $\begin{array}{l}\text { Reduced } \\
\text { Model }^{1}\end{array}$ & $\begin{array}{c}\text { Full } \\
\text { Model }^{2}\end{array}$ & $\begin{array}{l}\text { Reduced } \\
\text { Model }^{1}\end{array}$ & $\begin{array}{c}\text { Full } \\
\text { Model }^{2}\end{array}$ & $\begin{array}{l}\text { Reduced } \\
\text { Model }^{1}\end{array}$ & $\begin{array}{c}\text { Full } \\
\text { Model }^{2}\end{array}$ \\
\hline Intercept & $\begin{array}{c}0.14 \\
(0.37)\end{array}$ & $\begin{array}{l}-1.46^{* *} \\
(0.32)\end{array}$ & $\begin{array}{l}0.22^{* *} \\
(0.10)\end{array}$ & $\begin{array}{c}0.03 \\
(0.13)\end{array}$ & $\begin{array}{l}-0.74^{* *} \\
(0.348)\end{array}$ & $\begin{array}{l}-2.18^{*} \\
(0.57)\end{array}$ & $\begin{array}{l}-1.13^{*} \\
(0.37)\end{array}$ & $\begin{array}{l}-1.57^{*} \\
(0.43)\end{array}$ \\
\hline PS or & $0.99^{*}$ & $0.99^{*}$ & $1.00^{*}$ & $1.00^{*}$ & $1.00^{*}$ & $1.00^{*}$ & $0.99^{*}$ & $1.00^{*}$ \\
\hline $\begin{array}{l}\mathrm{RB}^{3} \\
\mathrm{AB}\end{array}$ & (0.006) & $(0.005)$ & $(0.002)$ & $(0.002)$ & $(0.006)$ & $\begin{array}{c}(0.006) \\
0.88^{*} \\
(0.44)\end{array}$ & $(0.006)$ & $\begin{array}{c}(0.004) \\
0.87^{*} \\
(0.32)\end{array}$ \\
\hline Risk $_{6}$ & & $\begin{array}{l}0.67^{* *} \\
(0.30)\end{array}$ & & $\begin{array}{c}0.04 \\
(0.09)\end{array}$ & & $\begin{array}{c}0.48 \\
(0.65)\end{array}$ & & $\begin{array}{c}0.78 \\
(0.47)\end{array}$ \\
\hline Risk $_{7}$ & & $\begin{array}{l}0.81^{*} \\
(0.28)\end{array}$ & & $\begin{array}{l}0.32^{*} \\
(0.10)\end{array}$ & & $\begin{array}{c}0.86 \\
(0.56)\end{array}$ & & $\begin{array}{c}0.60 \\
(0.42)\end{array}$ \\
\hline $\mathrm{Risk}_{8,9}$ & & $\begin{array}{l}0.65^{* *} \\
(0.33)\end{array}$ & & $\begin{array}{l}0.41^{*} \\
(0.12)\end{array}$ & & $\begin{array}{l}-0.45 \\
(0.95)\end{array}$ & & $\begin{array}{l}-0.03 \\
(0.70)\end{array}$ \\
\hline SubPerf & & $\begin{array}{l}0.65^{*} \\
(0.23)\end{array}$ & & $\begin{array}{l}-0.15^{* * *} \\
(0.08)\end{array}$ & & $\begin{array}{l}2.46^{*} \\
(0.90)\end{array}$ & & $\begin{array}{l}1.55^{*} \\
(0.58)\end{array}$ \\
\hline $\mathrm{S}_{2}$ & & $\begin{array}{l}1.93^{*} \\
(0.26)\end{array}$ & & $\begin{array}{c}0.12 \\
(0.09)\end{array}$ & & $\begin{array}{c}0.22 \\
(0.45)\end{array}$ & & $\begin{array}{c}-0.0008 \\
(0.34)\end{array}$ \\
\hline $\mathrm{S}_{3}$ & & $\begin{array}{c}0.75^{*} \\
(0.27) \\
\end{array}$ & & $\begin{array}{c}0.11 \\
(0.10) \\
\end{array}$ & & $\begin{array}{c}0.60 \\
(0.44) \\
\end{array}$ & & $\begin{array}{l}-0.07 \\
(0.33)\end{array}$ \\
\hline $\mathrm{R}^{2}$ & .993 & .995 & .999 & .999 & .994 & .995 & .915 & .999 \\
\hline D-W & 1.65 & 2.12 & 1.97 & 2.05 & 1.87 & 2.06 & 1.75 & 2.03 \\
\hline $\begin{array}{l}{ }^{2} \text { Significal } \\
{ }^{1} \text { Yule-Wa } \\
\text { correlatior } \\
{ }^{2} \text { Because } \\
\text { Watson (D } \\
\text { model acr } \\
\text { estimate } r \\
0.11 \text { and s } \\
{ }^{3} \text { PS (priva } \\
\text { applicable } \\
\text { - No cond }\end{array}$ & $\begin{array}{l}\text { at } \alpha=.01 \text {. } \\
\text { er estimate } \\
\text { ere is no se } \\
\text { W) is appro } \\
\text { s auction s } \\
\text { 's for the } a \\
\text { ond stage } \\
\text { signal) is } \\
\text { the subse } \\
\text { on index w }\end{array}$ & $\begin{array}{l}\text { Significan } \\
\text { of the star } \\
\text { ial correla } \\
\text { imated by } \\
\text { sions are } \\
\text { ymmetric } \\
11,0.10 \\
\text { plicable t } \\
\text { lent drop- } \\
\text { greater th }\end{array}$ & $\begin{array}{l}\text { at } \alpha=.05 \text {. } \\
\text { ard errors } \\
\text { n, OLS es } \\
\left(1-\mu_{\rho}\right) . \mathrm{T} \\
17,0.03 \text { a } \\
\text { atment fir } \\
\text { d }-0.03 \text {. } \\
\text { he first dr } \\
\text { t bids per } \\
\text { n } 20 \text { for an }\end{array}$ & $\begin{array}{l}\text { Significa } \\
\text { e reported } \\
\text { nates are } \\
\text { estimate } \\
\text {-0.04 an } \\
\text { stage moc } \\
\text {-out bid p } \\
\text { uation (4) } \\
\text { model (G }\end{array}$ & $\begin{array}{l}\text { at } \alpha=.10 \text {. } \\
\text { or the redu } \\
\text { ported for } \\
\text { ho's for the } \\
\text { second stag } \\
1 \text { across auc } \\
\text { equation } \\
\text { ene } 2003 \text {, }\end{array}$ & $\begin{array}{l}d \text { models } \\
\text { full mod } \\
\text { ymmetric } \\
0.05,-0.0 \\
\text { on sessior } \\
\text { and RB ( } \\
\text { 58). }\end{array}$ & $\begin{array}{l}\text { le to positi } \\
\text { s. The Durb } \\
\text { eatment fir } \\
\text { and } 0.04 \text {. } \\
\text { are }-0.19 \text {, } \\
\text { servation b }\end{array}$ & $\begin{array}{l}\text { e serial } \\
\text { in- } \\
\text { t stage } \\
\text { Che } \\
20 \text { and - } \\
\text { d) is }\end{array}$ \\
\hline
\end{tabular}


Table 5: Capacity Treatment Results Testing Null Hypothesis 3 (Surplus Transference) for Observed (OBS) and Risk Neutral Nash Equilibrium (RNNE) Simulations

Symmetric Capacity

(5 Bidders)

\begin{tabular}{cccc}
\hline OBS & RNNE & OBS & RNNE \\
\hline $\begin{array}{cccc}\text { Average Prices } \\
\text { (Std. Dev. })\end{array}$ & $\begin{array}{c}\text { Average Prices } \\
\text { (Std. Dev.) }\end{array}$ & $\begin{array}{c}\text { Average Per } \\
\text { (Std. Dev. })\end{array}$ & $\begin{array}{c}\text { Average Per } \\
\text { (Std. Dev.) }\end{array}$ \\
\hline 56.47 & 56.21 & $0.39^{\text {a1,b1 }}$ & $0.65^{\text {al,b2 }}$ \\
$(20.72)$ & $(20.61)$ & $(1.79)$ & $(1.81)$ \\
\hline
\end{tabular}

Joint Venture and Asymmetric Capacity

(3 Bidders)

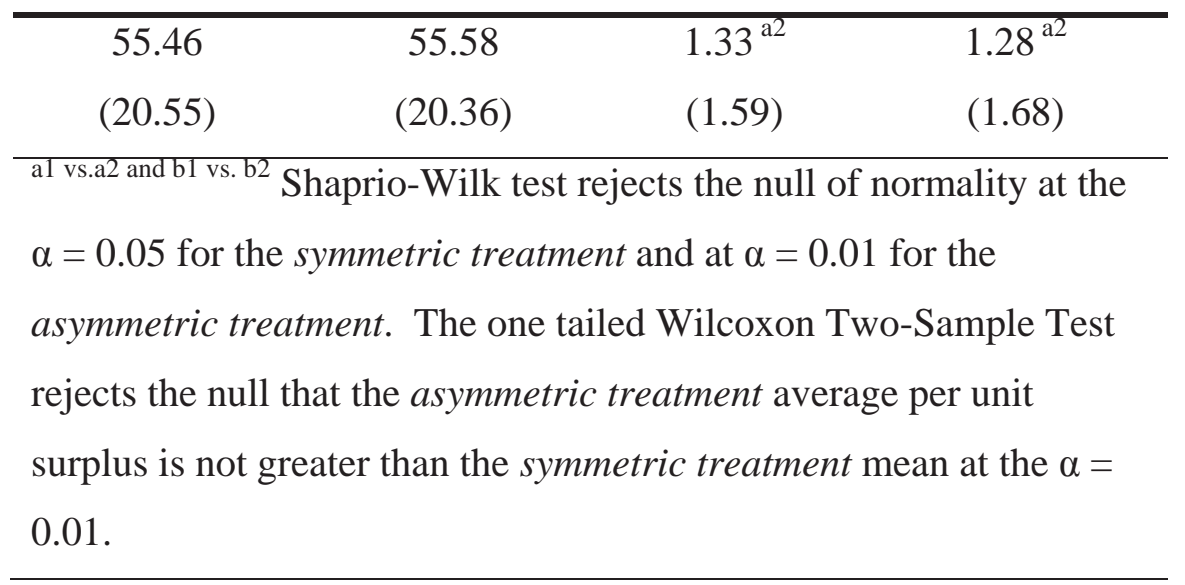


Figure 1: Backward Induction Pre-test (Centipede Game)

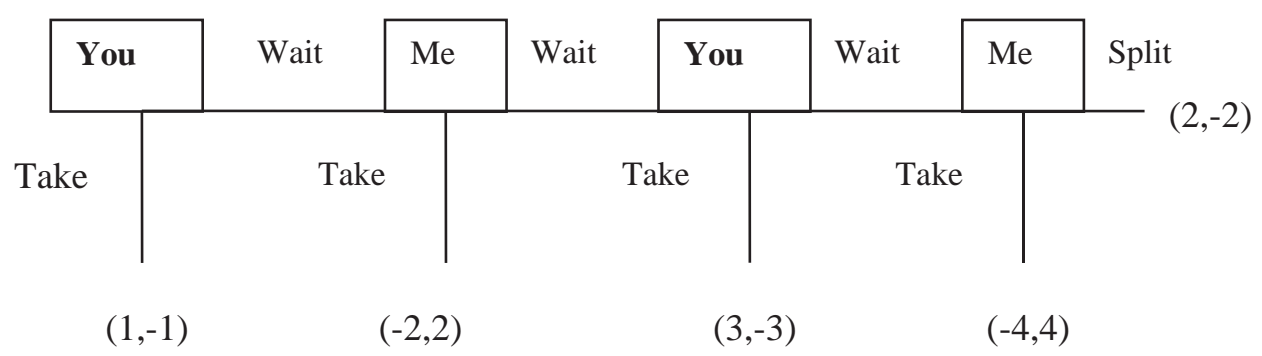

Figure 2: Percentage Wins per Unit by the Advantaged (AB) and Disadvantaged Bidders (DB)

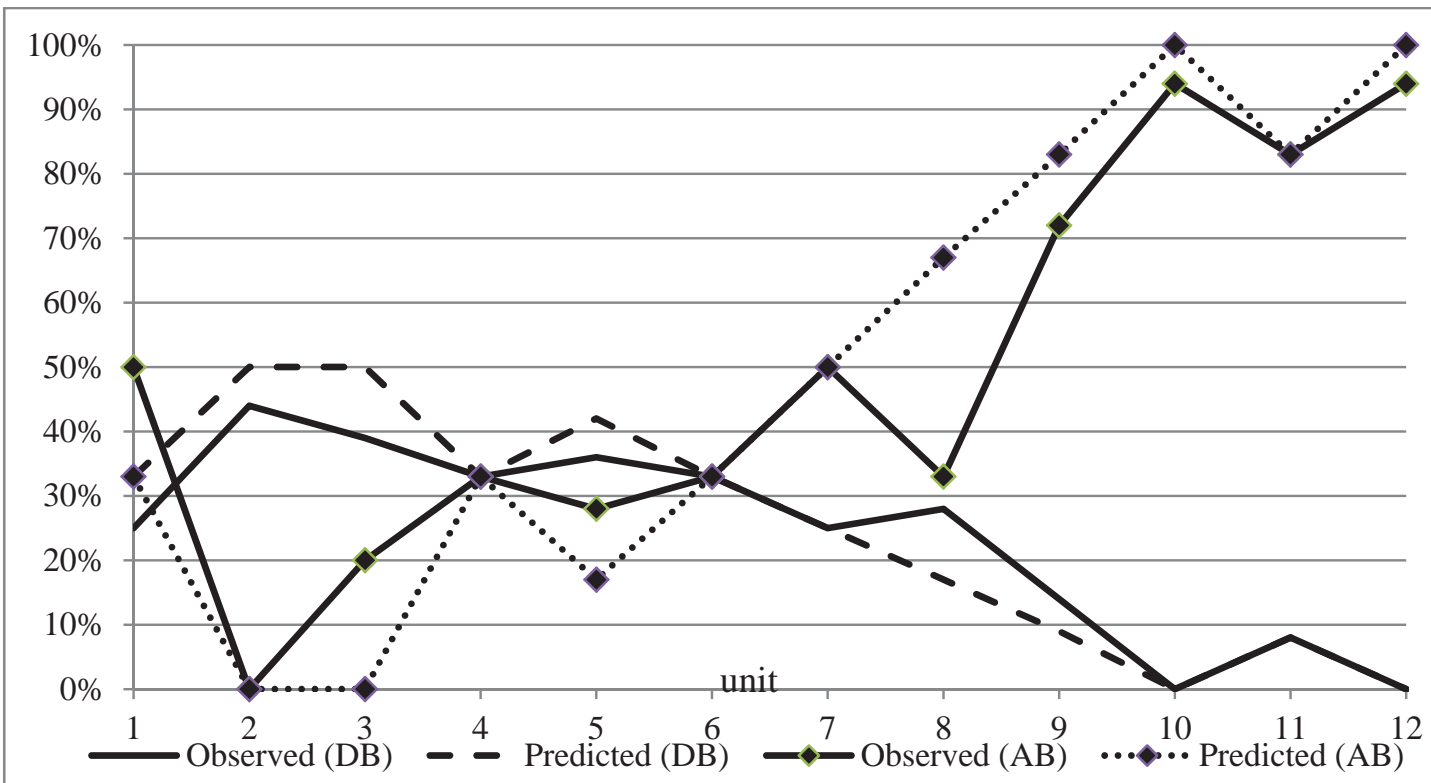




\section{References}

Ashenfelter, O. "How Auctions Work for Wine and Art." Journal of Economic Perspectives, Vol. 3, No. 3, (Summer 1989): pp. 23-36.

Bernhardt, D. and D. Scoones. "A Note on Sequential Auctions." The American Economic Review, Vol. 83, No. 4, (June, 1994): pp. 653-657.

Bikhchandani, S. "Reputation in Repeated Second-Price Auctions." Journal of Economic Theory, Vol. 46, (1988): pp. 97-119.

Binmore, K., J. McCarthy, G. Ponti, L. Samuelson and A. Shaked. "A Backward Induction Experiment." Journal of Economic Theory, Vol. 104, (2002): pp. 48-88.

Buccola, S.T. "Price Trends at Livestock Auctions." American Journal of Agricultural Economics, Vol. 64, No. 1, (February, 1982): pp. 63-69.

Casari, M., J. C. Ham and J. H. Kagel. "Selection Bias, Demographics Effects, and Ability Effects in Common Value Auction Experiments.” American Economic Review, Vol. 97, No. 4, (September 2007): pp. 1278-1304.

Coatney, K.T., S.L. Shaffer and D.J. Menkhaus. “Auction Prices, Market Share, and a Common Agent.” Journal of Economic Behavior and Organization, Vol. 81, (2012): pp. 61-73.

Coatney, K.T. and J.B. Tack. "Estimating the Value of Antitrust Investigations: A Case Study in Agriculture.” Agricultural and Applied Economics Association Annual Meeting, 2011, (Last accessed March 2011), http://ageconsearch.umn.edu/bitstream/103548/2/AAEA2011_Manuscript.pdf .

Corts, K.S. "Stacking the Deck: Idling and Reactivation of Capacity in Offshore Drilling." Journal of Economics and Management Strategy, Vol. 17. No. 2, (May 2008):271-294. 
Fatima, S.S., M. Wooldridge and N.R. Jennings. "Sequential Auctions for Objects with Common and Private Values." In proceedings of the Fourth International Joint Conference on Autonomous Agents and Multi-Agent Systems (AAMAS-05), Utrecht, the Netherlands, (July 2005): pp. 635-642.

Federal Trade Commission (FTC/DOJ). Competition in the Health Care Marketplace: Statements of Health Care Antitrust Enforcement Policy, Issued by the U.S. Department of Justice and the Federal Trade Commission, (August 1996), (Last Updated July 2009), http://www.ftc.gov/bc/healthcare/industryguide/policy/index.htm (Last accessed July 2013).

Fey, M., R.D. McKelvey and T.R. Palfrey. "An Experimental Study of Constant-sum Centipede Games." International Journal of Game Theory, Vol. 25, (1996): pp. 269-287.

Garvin, S. and J. H. Kagel. "Learning in Common Value Auctions: Some Initial Observations." Journal of Economic Behavior and Organization, Vol. 25, No. 3, (December 1994): pp. $351-372$

Greene, W.H. Econometric Analysis, 5th ed. Macmillan Publishing, New York (2003).

Hansen, R. G. and J. R. Lott, Jr., "The Winner's curse and Public Information in Common Value Auctions: Comment.” The American Economic Review, Vol. 81, No. 1, (March 1991): pp. 347-361.

Hendricks, K. and R.H. Porter. "Joint Bidding in Federal OCS Auctions.” The American Economic Review: Papers and Proceedings 82(2), (1992):506-511.

Holt, C.A. and S.K. Laury. "Risk Aversion and Incentive Effects." The American Economic Review, Vol. 92, No. 5, (December 2002): pp. 1644-1655. 
Inform Economics, Inc. “An Estimate of the Economic Impact of GIPSA's Proposed Rules”, prepared for National Meat Institute, (2010), (Last accessed March 2011), http://nppc.org/uploadedfiles/GipsaReport-Final2,2010-11-09.pdf.

Johnson, E.J., C. Camerer, S. Sen and T. Rymon. "Detecting Failures of Backward Induction: Monitoring Information Search in Sequential Bargaining." Journal of Economic Theory, Vol. 104, (2002): pp. 16-47.

Kagel, J.H. "Auctions: A Survey of Experimental Research.” in The Handbook of Experimental Economics, ed. J.H. Kagel and A.E. Roth, Princeton University Press, (1995): pp. 501585.

Kagel, J. H. and J.F. Richard. "Super-Experienced Bidders in First-Price Common-Value Auctions: Rules of Thumb, NASH Equilibrium Bidding, and the Winner's Curse.” The Review of Economics and Statistics, Vol. 83, No. 3, (August 2001): pp. 408-419.

Klemperer, P.D. “Auctions with Almost Common Values: The 'Wallet Game' and Its Applications.” European Economic Review, Vol. 42, (1998): pp. 757-769.

Levin, D., J.H. Kagel. “Almost Common Value Auctions Revisited.” European Economic Review, Vol. 49, (2005): pp. 1125-1136.

Levin, D., J. H. Kagel, and J. F. Richard. "Revenue Effects and Information Processing in English Common Value Auctions.” The American Economic Review, Vol. 86, No. 3, (June 1996): pp. 442-460.

Levitt, S.D., J.A. List and S.E. Sadoff. "Checkmate: Exploring Backward Induction Among Chess Players.” The American Economic Review, Vol. 86, No. 3, (June 1996): pp. 442460. 
Loureiro, M. L., W. J. Umberger and S. Hine. "Testing the Initial Endowment Effect in Experimental Auctions.” Applied Economic Letters, Vol. 10, (2003): pp. 271-275.

McAfee, R.P. and D. Vincent. "The Declining Price Anomaly.” Journal of Economic Theory, Vol. 60, (1993): pp. 191-212.

McKelvey, R.D. and T.R. Palfrey. "An Experimental Study of the Centipede Game." Econometrica, Vol. 60, No. 4, (July 1992): pp. 803-836.

Milgrom, P.R. and R.J. Weber. "A Theory of Auctions and Competitive Bidding." Econometrica, Vol. 50, No. 5, (September 1982): pp. 1089-1122.

Porter, R.H. "Detecting Collusion.” Review of Industrial Organization, Vol. 26, (2005): pp.147167.

Rose, S.L., D. Levin. “An Experimental Investigation of the Explosive Effect in Almost Common Value Auctions.” Journal of Economic Behavior and Organization, Vol. 67, (2008): pp. 927-946.

Rose, S.L. and J.H. Kagel. "Almost Common Value Auction: An Experiment.” Journal of Economics \& Management Strategy, Vol. 17, No. 4, (2008): pp. 1041-1058.

U.S. Department of Agriculture, Grain Inspection, Packers and Stockyards Administration. 2007. GIPSA Livestock and Meat Marketing Study, (Last accessed July 2013), http://www.gipsa.usda.gov/Publications/psp/livemarketstudy/LMMS_Vol_3.pdf

U.S. Department of Agriculture, Grain Inspection, Packers and Stockyards Administration. 2008. Packers and Stockyards Statistical Reports. Available at http://www.gipsa.usda.gov/GIPSA/webapp?area=newsroom\&subject=landing\&topic=pu b-stat. (Last accessed July 2013). 
Weber, R.J. “Multiple-object Auctions.” In: Engelbrecht-Wiggans, R., Shubik, M., Stark, R.M. (Eds.), Auctions, Bidding and Contracting: Uses and Theory. New York University Press, (1983): pp. 165-191. 


\section{Appendix A: Derivation of the Bidder Competition Path - Units 7 through 12 - Asymmetric}

\section{Capacity Treatment}

Assuming bidding strategies are symmetric, capacity disadvantaged bidders (DBs) and the capacity advantaged bidder (AB) have an equally likely chance of winning units 1 to 7 . From the negative binomial distribution bidders replace the probability of facing three bidders for unit $7, \operatorname{prob}(b=3,7)=1$, with its certainty equivalent. The probability any given bidder $b$ wins unit 7 is $\operatorname{prob}(b$ win 7$)=1 / 3$ and the probability one of the $D B$ will win unit 7 is $\operatorname{prob}(D B$ win 7$)=2 / 3$. If one of the $D B$ wins unit $7, b=2$ for unit 8 and $\operatorname{prob}(b$ win 8$)=1 / 2$. If $A$ wins unit $7, b=3$ for unit 8 and $\operatorname{prob}(b$ win 8$)=1 / 3$ and the probability one of the $D B$ will win unit 8 is $\operatorname{prob}(D B$ win 7) $=2 / 3$, and so on. Table A.1 summarizes the approximate joint probabilities over the expected bidder profiles for units 7 through 12, with the most likely in bold.

Table A.1: Joint Probabilities over Bidder Competition Profiles per Unit

\begin{tabular}{lllllll} 
Unit & 7 & 8 & 9 & 10 & 11 & 12 \\
& & & & & & \\
\hline $\operatorname{prob}(b=3)$ & $\mathbf{1}$ & .3333 & .1111 & .0370 & .0123 & .0041 \\
$\operatorname{prob}(b=2)$ & 0 & .6667 & .5556 & .3519 & .2006 & .1024 \\
$\operatorname{prob}(b=1)$ & 0 & 0 & .3333 & $\mathbf{. 6 1 1 1}$ & $\mathbf{. 7 8 7 0}$ & $\mathbf{. 8 8 7 3}$
\end{tabular}

Three bidders are expected to compete up through the $7^{\text {th }}$ unit, where the $7^{\text {th }}$ unit represents the expected breaking point for a reduction in the number of competing bidders. There likely will be 2 bidders competing for units 8 and 9 . This is because $\mathrm{AB}$ has a higher joint probability of winning the $8^{\text {th }}$ unit. At unit 9 , the auction game is expected to end as a DB has a higher joint probability of winning. All bidders expect the $\mathrm{AB}$ to purchase units 10,11 and 12 uncontested. 